\title{
Vzpomínky na vývoj katedry mezinárodního (a evropského) práva $v$ Brně a rozvoj oborů mezinárodní právo veřejné a právo EU v letech 1974-2019
}

Reminiscences of the Evolution of the International (and European) Law Department on Brno and the Development of the Academic Disciplines of Public International Law and EU Law during the Period from 1974 to 2019

Vladimír Týč*

\begin{abstract}
Abstrakt
Cíl této studie je dvojí. Je préedevšim stručným pobledem na historii katedry mezinárodního (a evropskébo) práva od jejího založeni do současnosti, zejména pokud jde o personálni složeni a odborné zamèrení. Drubým cílem je zmapováni a vyhodnocení prǐnosu katedry k rozvoji obori mezinárodní právo veréjné a právo EU, věetně větve duserníbo vlastnictví. O oboru mezinárodni právo sonkromé pojednává zulástni studie.

Pro prehlednost je text členèn do trù cástí, odpovidajicich trem obdobim: prvni do roku 1990, drubé poté do roku 2010 a tretí zahrnujici posledni léta a souíasnost. Zatímco prvni obdobi bylo ve znameni rozjezdu a budováni nové katedry na nové fakulté, drubé obdobi znamenalo v nových podminkách bourlivý rozvoj odborné i pedagogické cinnosti. Katedra rozšririla svoji prisobnost o nový velmi dynamický obor právo Evropské unie. V posledním obdobi do současnosti pokračuje bohatá vědecké a pedagogická činnost a stabilizuje se personálni složeni týmu katedry.

Studie dochází k závèru, že katedra významnou mèrou príspivá k rozvoji svých oborì, zajištuju bohatou a hodnotnou pedagogickou činnost a dostala se tak na špičku podobných pracovišt'v ČR $^{2}$.
\end{abstract}

Klíčová slova

Mezinárodni právo verejné; právo EU; katedra mezinárodníbo a evropského práva; odborné publikace; pedagogická cinnost; prinos ke rozvoji jednotlivých obori.

\section{Abstract}

The aim of the study is twofold. First of all it provides a brief look at the history of the International (and European) Law Department from its establishment until present, especially as far as the composition of its staff is concerned. Second aim is to survey and evaluate of the Department's contribution to the development of fields of public international law and EU law, including a special branch of intellectual property. The field of private international law has been examined in a separate study.

Prof. JUDr. Vladimír Týč, CSc., Katedra mezinárodního a evropského práva, Právnická fakulta, Masarykova univerzita, Brno / Department of International and European Law, Faculty of Law, Masaryk University, Brno, Czech Republic / E-mail: Vladimir.Tyc@law.muni.cz 
To be more clear the text has been divided into three parts corresponding to three time periods: the first one until 1990, the second one after until 2010 and the third one embracing recent years and current state. While the first period was marked by starting efforts and creation and building of a new department at a new faculty, the second period was characterised by an intensive development of both scientific and educational activities under new political conditions. The Department expanded the scope of its activities to the European law. In the latest period and at present intensive scientific and educational activities continue and the staffing of the Department tend to be stabilised.

The conclusion of the study is that the Department contributes in a decisive manner to the development of international and European law, provides rich and valuable educational activities and consequently belongs to the top scientific and educational bodies in the Crech Republic in those fields.

\section{Keywords}

Public International Law; EU Law; International and European Law Department; Scientific Publications; Educational Activities; Contribution to the Development of Particular Fields.

\section{Úvod}

Při vzniku, resp. obnovení brněnské právnické fakulty v rámci Univerzity Jana Evangelisty Purkyně v Brně v roce 1969, vznikla i katedra mezinárodního práva jako víceoborové pracovišstě.

Katedra mezinárodního práva v Brně byla koncipována tradičním způsobem stejně jako v Praze a Bratislavě, tedy zahrnovala obory mezinárodního práva veřejného (MPV) a mezinárodního práva soukromého (MPS), byt' jde o dva obory podobné názvem, ale velmi odlišné svou podstatou. Oboru mezinárodní právo soukromé se věnuje samostatná část tohoto zvláštního vydání ČPVP.

Připomeňme, že v tehdejší české části československé federace dosud existovala katedra mezinárodního práva jen v Praze, a na Slovensku pouze v Bratislavě (a později ještě v Košicích).

Podívejme se nyní na život katedry a rozvoj oborů mezinárodní právo veřejné a později právo EU ve třech etapách. První zahrnuje období od vzniku do roku 1989, druhé zhruba dvě desetiletí po převratu a třetí poslední desetiletí do současnosti.

\section{I. období: 1969-1989}

Při zrodu katedry stál Vladislav David (MPV) se svým kolegou Otakarem Ellerem (MPS). K nim se připojili v roce 1974 dva z prvních absolventů nové fakulty - Jiří Malenovský a Václav Mikulka (oba MPV), jakož i Vladimír Týč (MPS, později MPV), který právě přesídlil na Moravu z Prahy. Tato pětice tvořila původní základ katedry, budované takřka od nuly, ale s o to větším nadšením. Katedra tak plně fungovala od roku 1974. Fakulta tehdy sídlila na Nám. 25. února (Zelný rynek). 
S tímto počátkem má autor tohoto textu spojené velmi specifické vzpomínky. Jako nezku-

šený př́stěhovalec z Čech neznalý Brna byl ochotně „zaučován“ Jiřím Malenovským, a objevil tak hned pod okny na Zelném rynku doposud jemu neznámé atrakce - burčák a grilovaná cigára. Chápání novinek bylo náročné, protože instruktor hovořil, zřejmě trochu zlomyslně, silným brněnským dialektem, pro Pražana téměř nesrozumitelným.

Personální složení katedry se časem mírně změnilo - Václav Mikulka a poté i Vladimír Týč po několika letech odešli na praktická pracoviště tuzemská i zahraniční a byli nahrazeni mladšími absolventy fakulty - Naděždou Rozehnalovou (MPS) a Daliborem Jillkem (MPV).

Již v celém tomto období byla katedra velmi dynamickým a brzy i prestižním pracovištěm, které zajišt'ovalo rozsáhlou pedagogickou a vědeckou činnost v obou oborech mezinárodním právu veřejném a soukromém.

\subsection{Vědecká a publikační činnost}

Základním věcným předpokladem vědecké činnosti jsou odborné zdroje, zejména zahraniční. Pro tuto dobu byl charakteristický nedostatek zahraniční literatury ze západních zemí. Východní literatura nebyla problémem. Mnohé odborné publikace zejména z Polska a SSSR byly velmi zajímavé a jazykově srozumitelné, avšak pochopitelně nestačily. Na nákup západních publikací nebyl dostatek deviz, takže každý rok se jich nakupoval jen minimální počet. O to pečlivěji byly tyto publikace studovány. Handicap nedostatku západní literatury byl částečně překonáván využíváním fondu knihovny pražské právnické fakulty (na základě vzájemnosti), a také knihovny ministerstva zahraničních věcí, která byla zásobena západními publikacemi velmi dobře (na základě dobrých osobních kontaktů).

Dalším faktorem vědecké činnosti je prezentace jejích výsledků. I zde byly velké problémy. Stručně řečeno - nebylo téměř kde publikovat. Z právnických časopisů byl k dispozici jen Právník a Socialistická zákonnost, př́ípadně slovenský Právny obzor, tedy periodika obecně právně zaměřená. Časopis pro mezinárodní právo byl v r. 1969 zastaven a jako specializovaná publikace zbyly jen Studie z mezinárodního práva, vycházející v ČSAV jako sborník vědeckých statí jednou ročně. Monografie nebo rozsáhlejší studie bylo možno publikovat $\mathrm{v}$ univerzitní publikační řadě Acta Universitatis Brunensis-Iuridica (AUB-I, Sborník prací učitelů Právnické fakulty), rovněž ale s omezenou kapacitou. Při výběru textů $\mathrm{k}$ publikaci byla dávána přednost spíš starším učitelům před mladými. Přesto se práce členů katedry v uvedených publikacích objevovaly.

Další formou prezentace výsledků vědecké činnosti byly vědecké konference. Účast na zahraničních konferencích byla prakticky vyloučena, a proto byly pořádány $\mathrm{v}$ maximální míře konference tuzemské, někdy s účastí zahraničních učitelů, zejména z družebních univerzit ve východní Evropě. Výhodou těchto konferencí byla takřka neomezená prezentační kapacita - každý zájemce mohl formou př́spěvku bez omezení prezentovat 
své poznatky a hlavně se jakožto zpětnou vazbu dozvědět připomínky uplatněné v diskusi, zejména od starších kolegů. Brněnská katedra se tak brzy dostala do povědomí mezinárodně právní komunity jako velmi produktivní, a tím pozoruhodné pracoviště.

Pokud jde o věcné zaměření publikační činnosti v oboru mezinárodního práva veřejného v 70. a 80. letech, je třeba uvést monografie a další publikace Vladislava Davida publikované v řadě AUBI na téma mezinárodní odpovědnosti státu, mezinárodních zločinů, sankcí v mezinárodním právu a právního režimu Západního Berlína. Společně s Jiřím Malenovským sepsali oba autoři monografii Mezinárodně právní aspekty potlačování mezinárodního terorismu (1983).

Značnou pozornost vyvolaly dvě monografické publikace spoluautorů Vladislav David Čestmír Čepelka (PrF UK), a to Úvod do mezinárodního práva (1978) a nové vydání pod názvem Úvod do teorie mezinárodního práva (1983). Př́ístup autorů k některým zahrnutým otázkám obecné části mezinárodního práva byl na jejich dobu poněkud netradiční a tvưrčí, čímž tyto publikace vzbudily v celostátním měřítku značnou pozornost.

Jiří Malenovský publikoval v časopisu Právník a ve Studiích z mezinárodního práva. Zabýval se kromě mezinárodního terorismu zpočátku zejména mořským a kosmickým právem, avšak v širších souvislostech. Pozoruhodná je především jeho studie $\boldsymbol{O d}$ „res communis omnium“ ke „společnému dědictví lidstva“ publikovaná v časopisu Právník v roce 1978. Již v této době ho zaujala hlavně obecná část mezinárodního práva, která je základem jeho odborné činnosti dodnes. Po dvou pojednáních o utváření mezinárodního obyčeje (Právník, 1984 a 1987) následovaly stat’ o systémovém pojetí mezinárodního práva (Studie z mezinárodního práva, 1988) a samostatná publikace na toto téma v r. 1990 (viz dále).

Dalibor Jílek se v tomto období soustředil na otázku mezinárodně právní odpovědnosti mezinárodních organizací, kde publikoval studie v Právníku (1984) a ve Studiích z mezinárodního práva (1986).

Václav Mikulka se kromě pojetí sebeobrany v mezinárodním právu věnoval hlavně sukcesi států, nejprve do smluv (Právník, 1976) a po odchodu z fakulty, zejména už jako člen Komise pro mezinárodní právo OSN, i ostatními aspekty sukcese států.

Prioritou Vladimíra Týče v oboru MPV byly mezinárodní smlouvy a zejména jejich vztah k vnitrostátnímu právu. O důvodech počáteční neplatnosti mezinárodních smluv pojednává jeho stat' ve Studiích z mezinárodního práva (1980) a o vztahu smluv k vnitrostátnímu právu pozdější článek v Právníku.

Z uvedeného přehledu je patrné, že přes všechny zmíněné problémy tohoto období byla katedra v oboru mezinárodního práva veřejného publikačně velmi životaschopná.

$\mathrm{Na}$ katedře studovali také interní aspiranti (dnes doktorandi), avšak početně byli velmi vzácní. Byl mezi nimi např. dnešní doc. JUDr. Martin Janků, CSc., který stále s katedrou externě spolupracuje. 


\subsection{Pedagogická činnost}

Jako oborové učebnice bylo v této době možno používat jen ty, které byly celostátně schválené Ministerstvem školství a kultury. Autorem velmi zdařilé celostátní učebnice mezinárodního práva veřejného byl tehdejší pražský docent, později profesor Miroslav Potočný, který navázal na svého předchůdce prof. Vladimíra Outratu.

Vyučovaly se jen povinné předměty, povinně volitelné neexistovaly. Výuka probíhala klasickým způsobem - formou přednášek a seminářù. Na rozdíl od dnešní doby byla pravidlem vysoká účast studentů na přednáškách, které byly i tehdy nepovinné. Studentů, kteří si studia považovali a měli zájem se něco dozvědět a naučit, bylo mnohem větší procento, než je tomu dnes. Zpočátku částečně vypomáhali s přednáškami a se zkoušením starší učitelé (docenti) z Prahy.

Zkouška byla po vzoru pražské katedry organizována jako souhrnná pro oba vyučované předměty, tedy dohromady z mezinárodního práva veřejného a soukromého. Zkoušela dvojčlenná komise, která stanovila jednu výslednou známku.

\subsection{Praktický život katedry}

Oproti dnešnímu stavu byla administrativní činnost na katedře minimální. Studenti byli hned v prvním ročníku přiděleni do stálých seminárních skupin, takže v průběhu studia se nikdo nikam neprrihlašoval ani neodhlašoval. Rozvrh seminářů jednotlivých skupin byl stanoven centrálně bez možnosti přesunů. Přihlašování na zkušební termíny obstarávalo studijní oddělení, a to bez možnosti odhlášení nebo posunutí termínu. Studijní oddělení také vedlo pro každého studenta studijní kartu, kam se zapisovaly výsledky zkoušek. Kromě toho se výsledky zapisovaly do indexu. Kdo neměl ke stanovenému datu hotové zkoušky, nemohl postoupit do dalšího ročníku. Takto fungovalo studium bez ISu. Tento rigidní systém vedl studenty k větší odpovědnosti za své studium, protože plnění studijních povinností nebylo možné donekonečna odsouvat, jako je tomu nyní. Sekretářka katedry tak kromě agendy diplomových prací studijní věci prakticky žádné nevyrrizovala. Znamenitým fenoménem této doby byla každoroční celostátní (federálnî) setkání kateder mezinárodního práva. Nevelký počet běžných služebních cest během roku z nich učinil prvořadou událost, která umožňovala udržovat úzký vzájemný osobní kontakt $\mathrm{v}$ rámci celé československé mezinárodně právní komunity. $\mathrm{V}$ pořádání těchto setkání se jednotlivé katedry (Praha, Brno, Bratislava, Košice) postupně stř́daly a bylo pravidlem, že se jich s velkou radostí účastnili všichni jejich členové. Setkání se konala zpravidla $\mathrm{v}$ rekreačních střediscích nebo podobných zařízeních př́slušných univerzit a trvala 2-3 dny. První polovina byla věnována pracovní části, zpravidla prezentaci výsledků odborné činnosti mladších členů s diskusí a druhá polovina pak společenským kontaktům, dalším diskusím odborným i neodborným včetně případných exkurzí po okolí. 
Náklady akce vždy z větší části hradila pořádající katedra. To byl někdy problém, protože fakultní prostředky nebyly v dostatečné výši k dispozici, i když se na tuto akci celý rok „šetřilo“. Pak bylo třeba hledat tvưrčím způsobem další zdroje. Naše katedra získala v jednom př́padě (1978) takové dodatečné prostředky jako výdělek z katedrové brigády na stavbě v Žabovřeskách na ul. Stránského. Dnes je v budově, kterou jsme pomáhali stavět, supermarket Billa a obchod Svět piva.

\section{II. období: 1989-cca 2010}

\subsection{Personální změny a odborné zaměření katedry}

Listopadové události v roce 1989 se na katedře projevily především změnou v jejím vedení - Vladislav David byl ve funkci vedoucího katedry vystř́idán Jiř́m Malenovským. Ten se po třech letech stal soudcem Ústavního soudu a poté vstoupil do zahraničních služeb, kde působí jako soudce Soudního dvora EU dodnes. Po celou dobu vyučuje na katedře na částečný úvazek. Vladimír Týč, který se mezitím na fakultu ze zahraničního působení vrátil, převzal takto uvolněnou funkci vedoucího katedry v roce 1992 a vykonával ji s několikaletou přetržkou, kdy se vystřídal s Daliborem Jílkem ve funkci proděkana, až do roku 2014.

Vladislav David (již jako profesor) a Otakar Eller (jako docent) z katedry na počátku 90. let odešli. Přetrvala tak jen část původní sestavy ve složení Naděžda Rozehnalová, Vladimír Týč a Dalibor Jílek. Katedra byla proto doplněna o několik nových mladých kolegů, kteří ale všichni po několika letech zase odešli. Dále v roce 1997 př́šel na katedru Filip Křepelka se specializací evropské právo a v roce 2004 se stejnou specializací David Sehnálek. V roce 2005 nastoupila na mezinárodní právo veřejné Kateřina Uhlírová (tehdy Novotná). Koncem roku 2008 naopak z katedry odešel Dalibor Jílek, a to v hodnosti profesora.

Nelze také opomenout dvě z nepřehlédnutelných sekretářek tohoto období, které se o zdárný chod katedry velkou měrou zasloužily. Po odchodu z katedry zůstaly věrny fakultě, posléze vystudovaly bakalářský, resp. magisterský program a zastávají dnes odpovědná místa ve fakultní administrativě. Jsou to Mgr. Jana Lautrbachová a Bc. Radka Schardová.

$\mathrm{V}$ roce 1992 došlo k revolučnímu počinu - oborový záběr katedry (MPV a MPS) byl rozšîren o třetí stěžejní obor, zcela nový - evropské právo. Na rozdíl od Prahy v Brně nebyly podmínky pro vytvoření samostatné nové katedry evropského práva, a proto nový obor byl svěřen původní katedře se změněným názvem „katedra mezinárodního a evropského práva“. Právo ES (později právo EU) se stalo dalším povinným katedrovým předmětem.

Do tohoto období spadají také začátky nového „podoboru“ - mezinárodního a evropského práva duševního vlastnictví. Odpovídal mu stejnojmenný povinně volitelný předmět. Záběr katedry se tak oproti minulému období velmi rozšśřili. 


\subsection{Vědecká a publikační činnost}

\subsubsection{Materiálnípodminky}

Pokud jde o fakultní finanční zdroje, situace se zpočátku neměnila, ale postupně se začaly objevovat nové zdroje vnější, a to v podobě nejrůznějších projektů a grantů. Zpočátku šlo o projekty malého rozsahu (např. v rámci Vzdělávací nadace Jana Husa), které ovšem umožnily alespoň v určitém rozsahu nákup další potřebné zahraniční literatury a úhradu nákladů krátkých zahraničních cest nezbytných pro řešení výzkumných úkolů. Po vzniku Grantové agentury ČR se mnozí členové katedry mohli ucházet o větší projekty a úspěšně je řešit, a to s dostatečným finančním zabezpečením. Po roce 2000 se zlepšila také finanční situace na univerzitě obecně, takže bylo možno i mimo granty z vlastního rozpočtu nakupovat literaturu a organizovat zahraniční služební cesty, především za účelem aktivní účasti na konferencích a krátkých studijních pobytů.

Zajímavou historii má zajištění pramenů pro nový obor evropské právo. $\mathrm{Na}$ počátku 90. let ještě fakulta dostatečné finanční prostředky na nákup nezbytné odborné literatury neměla. Vladimír Týč při návratu do Brna ze zahraničí sice několik publikací o evropském právu dovezl, ty ale byly jen kapkou v moři. Vypravil se proto na tehdejší spř́átelenou Právnickou fakultu Univerzity Paříž XI, aby identifikoval další nezbytné publikace a po konzultaci eventuálně některé z nich zakoupil. Výsledek návštěvy byl nečekaný. Fakulta poskytla bezprostředně a bez formalit finanční prostředky na nákup množství publikací ze svého projektu pro spolupráci s univerzitami ve východní Evropě, takže bylo možno ihned tyto knihy v knihkupectvích Latinské čtvrti zakoupit, naložit do auta a dovézt do Brna. Pro začátek výstavby nového oboru tyto zdroje stačily.

\subsubsection{Prezentace výsledkù}

Prezentace výsledků vědecké činnosti členů katedry doznala brzy změn. Po roce 1990 bylo v ČR založeno několik nových odborných periodik, které dávaly nové př́ležitosti k publikaci. Pro nás měl největší význam fakultní Časopis pro právni védu a praxi a tehdy existující z Nizozemí dotovaný časopis EMP (Evropské a mez̧inárodníprávo). Začalo se také publikovat v zahraničí úměrně s rozšiřováním zahraničních vztahů. Bylo možné se účastnit zahraničních vědeckých konferencí a ve větší míre pořádat konference tuzemské se zahraniční účastí. V rámci univerzity vznikla možnost vydávat vědecké monografie, at' už v rámci vědeckých projektů nebo mimo ně.

Již byly zmíněny granty. Ty nebyly jen zdrojem finančních prostředků, ale především stimulem pro kvalitní vědeckou práci. Poskytovateli grantů byla hlavně Grantová agentura ČR, Ministerstvo zahraničních věcí a některé nestátní organizace (Vzdělávací nadace Jana Husa). Velmi významné byly projekty evropské, zejména Jean Monnet Chair, udělený Evropskou komisí Vladimíru Týčovi v roce 1997. Jednalo se o rozsáhlý výukový 
projekt pro evropské právo, dosti štědře dotovaný, takže nadále nebyl problém financování nákupu další odborné literatury nebo účasti na mezinárodních konferencích k otázkám evropského práva.

Věcný obsah vědeckých výstupů byl následující:

\section{- Mezinárodní právo veřejné}

- Již v roce 1990 se objevují nová teoreticky zaměřená skripta Jiř́ho Malenovského: Úvod do systémového pojetí mezinárodního práva. Poté se do svého odchodu z fakulty na Ústavní soud (1992) tento autor věnoval především problematice lidských práv.

- Dalibor Jílek s výjimkou spoluúčasti na monografii Mezinárodní odpovědnost (spolu s Č. Čepelkou a P. Šturmou, 2003) a několika statí týkajících se rovněž odpovědnosti mezinárodních organizací zasvětil svoji odbornou činnost převážně ochraně lidských práv (zejména ochraně menšin) a hlavně azylu a uprchlictví. Se stejnými spoluautory se účastnil na monografii Azyl a uprchlictví v mezinárodním právu (1997) a rok předtím sepsal autorskou monografii Odpověd' mezinárodního práva na hromadné uprchlictví (1996). Od roku 2005 byl po několik let editorem každoročního sborníku pojednávajícího o jednotlivých aspektech společného evropského azylového systému (do r. 2008). V tomto duchu byla pojata i autorova další publikační činnost $\mathrm{v}$ tomto období.

- Vladimír Týč se v oblasti MPV nadále věnoval především mezinárodním smlouvám. Publikoval monografie Právo mezinárodních smluv (1995) a O vnitrostátní prímé závaznosti mezinárodních smluv (1996), jakož i řadu článků nebo kapitol v odborných knihách, které se týkaly vztahu mezinárodních smluv k vnitrostátnímu právu, jejich vnitrostátní aplikace a postavení smluv v právu EU (viz dále). To byla témata také jeho četných zahraničních přednášek jako hostujícího profesora ve Francii. V. Týč je rovněž autorem publikace Průmyslová a autorská práva v mezinárodním obchodě (1997).

- Kateřina Uhlírová (dřive Novotná) od počátku publikovala především články a kapitoly v odborných knihách v oblasti ochrany lidských práv, humanitárního a mezinárodního trestního práva, a to velmi často v zahraničí, kde rovněž mnohokrát na tato témata vystupovala na konferencích a s přednáškami na zahraničních univerzitách.

\section{- Právo EU}

- Od poloviny 90. let se rozběhla odborná činnost i v oboru právo ES (EU). V letech 1995 až 1999 katedra vydávala s přispěním Evropské komise každoročně Ročenku evropského práva, což byl sborník vědeckých statí na aktuální evropská témata. Ročenka se bohužel nedožila nového tisíciletí, protože Evropská komise přestala poskytovat dotaci v potřebné výši a další finanční krytí se nepodařilo sehnat. 
- Monografická tvorba $\mathrm{v}$ tomto období představovala především spojení s mezinárodním právem soukromým, které bylo komunitarizováno, tedy pohlceno právem evropským. Spolu s Naděždou Rozehnalovou publikoval Vladimír Týč Evropské mezinárodní právo soukromé (1998, s účastí Moniky Novotné), Evropský justiční prostor v civilních otázkách (2003) a Vnější obchodní vztahy $\boldsymbol{E} \boldsymbol{U}(2006)$. Dvě poslední publikace byly výstupy ze společného grantu GA ČR.

- V roce 2004 získal V. Týč dva projekty ministerstva zahraničních věcí. Jejich témata byla Následky porušení práva ES/EU pro ČR jako členský stát EU a pro fyzické a právnické osoby jako adresáty přímo použitelných komunitárních předpisů a Význam judikatury Soudního dvora ES v právním řádu ČR a role vládního zmocněnce pro zastupování před Soudním dvorem ES a Soudem prvního stupně. Ke každému z nich vznikl výstup, který byl publikován ministerstvem (2005).

- Další témata výstupů V. Týče se týkala Evropského soudního dvora, zejména jeho výkladové činnosti, ústavních předpokladů vstupu ČR do EU, vnitrostátní aplikace evropského práva v ČR, harmonizace daní v EU, jakož i komunitárního (unijního) práva mezinárodních smluv.

- Filip Křepelka se ve své odborné činnosti zabýval otázkami spojenými s členstvím ČR v EU a s některými spíše praktickými aspekty. V tomto období publikoval množství časopiseckých článků a příspěvků na konferencích a také tyto monografie: Evropské zdravotnické právo (2004) a Mnohojazyčnost Evropské unie a její diosledky pro českou právní praxi (2007).

- David Sehnálek se ve svých příspěvcích soustředil nejvíce na teoretické otázky obecné části práva EU, jako je výklad, přednost, zásada effet utile, aplikace práva EU národními soudy nebo mezinárodní smlouvy uzavřené EU.

- V roce 2004 vyšlo významné kolektivní dílo několika členů katedry pod redakcí V. Týče: Lexikon - Právo Evropské unie. Dalšími autory byli F. Křepelka, N. Rozehnalová, J. Munková, M. Tomášek a B. Pikna.

\subsection{Pedagogická činnost - předměty a učebnice}

\subsubsection{Mezinárodni právo}

Aktuální situace na počátku 90. let si vyžádala zlepšit informovanost studentů o mezinárodních organizacích: Ti sice měli k dispozici učebnici M. Potočného Mezinárodní organiz̧ace, žádoucí však bylo poskytnout dostupný, stručný a přehledný text. Tak vznikla v roce 1992 skripta Organizace spojených národio, Evropská společenství, Rada Evropy spoluautorů J. Malenovského, V. Davida a D. Jílka.

Pokud jde o základní učebnici mezinárodního práva veřejného, prof. Jiř́i Malenovský se na počátku 90. let dohodl s prof. Potočným, že jeho učebnice bude rozdělena 
do dvou dílů. Obecnou část převezme prof. Malenovský a zvláštní část si ponechá prof. Potočný. Již v roce 1993 publikuje prof. Malenovský první vydání své učebnice pod názvem Mezinárodní právo veřejné: obecná část. V roce 2000 vydal monografii Poměr mezinárodního a vnitrostátního práva: obecně a v českém právním raádu zvláště. Tu později připojil ke zmíněné učebnici (počínaje jejím 4. vydáním v r. 2004 pod názvem Mezinárodní právo veřejné: jeho obecná část a poměr $k$ vnitrostátnímu právu, zvláště $\boldsymbol{k}$ právu českému), které pak následně upřesnil na Mezinárodní právo veřejné: jeho obecná část a poměr k jiným právním systémům. Následovala další vydání takto doplněné učebnice a v současnosti již vychází vydání sedmé. Zvláštní část převzal po smrti prof. Potočného pražský docent Jan Ondřej. Malenovského učebnice obecné části mezinárodního práva, pravidelně aktualizovaná, je velmi komplexní a podrobnou publikací odborně na úrovni monografie. Její rozhodující význam pro rozvoj oboru je zřejmý.

Ve výuce MPV byla rozšiřrena část věnovaná mezinárodní ochraně lidských práv. Neexistence české učebnice byla překlenuta překladem francouzské učebnice profesora Fréderica Sudre Mezinárodni a evropské právo lidských práv, který pořídil Jiří Malenovský a který vyšel v roce 1997.

Kromě základního předmětu mezinárodní právo veřejné bylo zavedeno několik povinně volitelných předmětů, zejména z oblasti lidských práv a humanitárního nebo azylového práva. $\mathrm{V}$ angličtině byl vyučován předmět věnovaný uprchlickému právu a byl vybaven v roce 1999 skripty, která vytvořil široký kolektiv autorů s názvem Integrated English Language Course in Refugee Law.

Pro výuku práva duševního vlastnictví (povinně volitelný předmět) V. Týč sepsal v roce 1993 skripta Mezinárodní úprava ochrany průmyslových a autorských práv. Byla to první právnická skripta s ilustracemi.

\subsubsection{Právo EU}

Pravidelná výuka předmětu Právo Evropských společenství byla zahájena v roce 1992 jako předmět povinně volitelný a o rok později jako předmět povinný. Neexistence jakékoli učební pomůcky v českém jazyce byla rychle překonána: Dalibor Jílek a Vladimír Týč připravili pro tento účel první českou učební pomůcku, která vyšla v roce 1992 jako skripta a o rok později v rozšířené verzi jako učebnice s názvem Základy práva Evropských společenství. Byla to po všech stránkách prvotina, protože oba autoři se s evropským právem sami teprve seznamovali, ale svůj účel splnila.

V roce 1999 vyšlo první vydání zcela nové učebnice Vladimíra Týče Základy práva Evropských společenství (pozdęji Evropské unie) pro ekonomy. Př́istavek „pro ekonomy“ byl zvolen záměrně, aby tato právnická učebnice, psaná velmi srozumitelným jazykem, byla atraktivní i pro studenty ekonomických fakult. To umožnilo, alespoň zpočátku, zvýšit její odbyt, zvýšit tak náklad a tím o něco snížit cenu. Vždy po několika 
letech se prováděla (a dodnes provádî) aktualizace v podobě nového vydání. Dnes se již připravuje vydání osmé.

Kromě základního předmětu právo ES (dnes právo EU) byly zavedeny povinně volitelné předměty a vybaveny potřebnými učebními pomůckami (skripty). Byly to tyto tituly: Integrated European Case Law Course (autoři V. Týč a R. Šopovová 2003) a Soudnictví $\boldsymbol{V}$ institucionální struktuře EU (autoři V. Týč, F. Křepelka a D. Novák - 2006).

V roce 2007 bylo rozhodnuto vytvořit pro první ročník magisterského studia nový povinný jednosemestrální předmět Úvod do mezinárodního a evropského práva, aby studenti hned na počátku studia pochopili, že pojem právo se neomezuje jen na české právo, ale zahrnuje také právo mezinárodní a právo EU, které jsou v ČR rovněž závaznými právními systémy. První vydání stejnojmenných skript prripravil v témže roce V. Týč.

Právo EU je vyučováno také v bakalářském studijním programu. Pro tento program připravili skripta s názvem Právo Evropské unie. Multimediální učební text pro studenty bakalářských programů F. Křepelka, K. Skřivánková a D. Bacho (1. vyd. v roce 2005).

Jak právo mezinárodní, tak evropské je vyučováno i v doktorském studijním programu.

\section{III. období: 2010-2019 (současnost)}

\section{1 Život na katedře a personální změny}

Katedru nadále vedl V. Týč do roku 2015, kdy byl vystřídán F. Křepelkou. Na počátku tohoto období byly prüijaty další posily, a to pro MPV Zdeněk Nový a pro mezinárodní a evropské právo duševního vlastnictví Radim Charvát. Později (2017) posílila evropské právo ještě Iveta Rohová a MPV jako externista na částečný úvazek Ondřej Svaček z olomoucké fakulty. Po celou dobu trvá částečný úvazek Jiř́ho Malenovského. Sekretářkou katedry se stala Jana Dopitová. Definitivní současné složení katedry je uvedeno dále.

Administrativní fungování katedry není třeba popisovat - je založeno především na používání elektronického informačního systému (IS) a e-mailu, které každý zná. Pokud bylo konstatováno pro první období do r. 1989, že administrativní činnost katedry byla slabá, dnes je to pravý opak. Počet administrativních úkonů, které provádí sekretářka, vedoucí katedry a jednotliví učitelé se zmnohonásobil, i když IS některé z nich urychluje a usnadňuje. Některé počítačové operace jsou ale velmi obtížně zvládnutelné. V důsledku toho je administrativní práce s počítačem stále náročnější, mnozí s ním zdlouhavě zápasí a pomalu se s ním učí zacházet, místo aby se věnovali své vlastní odbornosti. Stejně je to s e-maily. Jejich vyřizování ubírá z času na odbornou a pedagogickou práci 
drahocenné minuty nebo spíše desítky minut denně. Ale to je problém celouniverzitní, a pravděpodobně i celostátní.

Jaký je osud společných schůzí českých a slovenských kateder mezinárodního (a evropského) práva, které byly zmíněny v části I? Odpověd’ je poněkud rozpačitá. Ve složitém popřevratovém období se tato společná zasedání téměř nekonala, protože je nikdo nesvolával. Poté byla postupně obnovena a v posledních 10 letech jsou opět konána pravidelně. Rozdíl je v tom, že počet kateder a jejich př́slušníků v ČR a SR se výrazně zvýšil, takže už není možné zvát všechny členy všech kateder. I tak se vždy účastní nejméně cca 40 osob. Někteří jezdí rádi a pravidelně, jiní nemají o tuto akci velký zájem. Časy se mění, osobní kontakt mezi členy komunity mezinárodního práva $\mathrm{v}$ bývalém Československu již pro mnohé není důležitý.

\section{Rekapitulace složení celé katedry v době vydání této publikace:}

doc. JUDr. Filip Křepelka, Ph.D. (právo EU) (vedoucí katedry)

prof. JUDr. Vladimír Týč, CSc. (MPV a právo EU)

prof. JUDr. Naděžda Rozehnalová, CSc. (MPS)

doc. JUDr. David Sehnálek, Ph.D. (právo EU)

JUDr. Klára Drličková, Ph.D. (MPS)

JUDr. Jiří Valdhans, Ph.D. (MPS)

JUDr. Tereza Kyselovská, Ph.D. (MPS)

JUDr. Radim Charvát, Ph.D., LL.M. (právo EU - duševní vlastnictvî)

JUDr. Kateřina Uhlírová, Ph.D., LL.M. (MPV)

Mgr. Zdeněk Nový, Ph.D., LL.M. (MPV)

Mgr. Iveta Rohová (právo EU)

Jana Dopitová (sekretářka)

\section{Externí učitelé na částečný úvazek:}

prof. JUDr. Jiří Malenovský, CSc. (částečný úvazek) (MPV)

JUDr. Ondřej Svaček, Ph.D., LL.M. (částečný úvazek) (MPV)

JUDr. Lucie Zavadilová (MPS - dočasná výpomoc)

Mgr. Radovan Malachta (MPS - dočasná výpomoc)

\subsection{Vědecká a publikační činnost}

Probíhala ve všech uvedených oborech. Materiální podmínky a možnosti prezentace výsledků byly velmi př́iznivé a oproti minulému II. období se nezměnily. 
Věcné zaměření vědeckých výstupů bylo následující:

\section{- Mezinárodní právo veřejné}

- V. Týč se nadále $\mathrm{v}$ oboru MPV věnoval mezinárodní smlouvě, např. výhradám a interpretačním prohlášením. V roce 2013 vypracoval souhrnnou odbornou publikaci Mezinárodní, české a unijní právo mezinárodních smluv. V oblasti ochrany lidských práv byl jedním z redaktorů a zároveň spoluautorem kolektivní monografie Mezinárodní lidskoprávní závazky postkomunistických zemí: př́klady České republiky a Slovenska (2016), která vyšla jako výstup úspěšného grantu GAČR. Dále publikoval příspěvky na téma sukcese státu a uznání státu.

- K. Uhlírová se ve své publikační a přednáškové činnosti tuzemské a zahraniční soustředila zejména na problematiku lidských práv z různých úhli̊, na válečné zločiny a mezinárodní trestní soudnictví (včetně uplatnění imunity), na Kosovo a další otázky, jako je např. kolektivní kriminalita nebo mezinárodní právo životního prostředí. Přednesla přednášky na několika evropských a amerických univerzitách. V roce 2013 vydala monografii Head of State Immunity in International Law. The Charles Taylor Case before the Special Court for Sierra Leone. Je členkou Akademického výboru síté evropských univerzit Utrecht Network za MU.

- Z. Nový se věnuje v první řadě právu mezinárodní investiční arbitráže, včetně imunity státu. Kromě toho publikoval prŕíspěvky na obecnější právní témata, jako např. systémová interpretace a fragmentace mezinárodního práva, evolutivní výklad mezinárodních smluv nebo paradox autonomie a vzájemné inkluzivity mezinárodního, evropského a vnitrostátního práva. Vydal dvě monografie: Dobrá víra jako princip smluvního práva v mezinárodním obchodu (2012) a Role veřejného zájmu v mezinárodní obchodní a investiční arbitráži (2017, společně s K. Drličkovou).

\section{- Právo EU}

- Vědeckovýzkumnou činnost v oboru právo EU významně poznamenal Výzkumný záměr MŠMT ČR „Evropský kontext vývoje českého práva po roce 2004“, na jehož řešení se zúčastnili všichni členové katedry se specializací právo EU. Výsledkem byly dvě významné monografické publikace týkající se aplikace unijního práva v ČR a jeho obecné ćásti vưbec: Přenos, doprovod a zohlednění evropského práva českým právem autora F. Křepelky (2010) a Vybrané otázky puisobení práva EU ve sférée českého právního rádu spoluautorů V. Týče, D. Sehnálka a R. Charváta (2011).

- Další významnou kolektivní publikací byla unikátní kniha vydaná v roce 2011 v USA společně s John Marshall Law School v Chicagu s titulem One or many? Vedoucími autorského kolektivu byli V. Týč, D. Sehnálek a M. P. Seng. Tato rozsáhlá publikace detailně vysvětluje právní systém Evropské unie a právní systém USA a oba systémy porovnává. Mezi české spoluautory z členů katedry patří rovněž R. Charvát. 
- Ještě další dva výstupy zasluhují zvláštní zmínku. Jsou to studie uveřejněné v roce 2017 v Právníku u př́ležitosti 60. výročí Rímských smluv o založení EHS a EURATOMu. Oběma bylo ze strany Akademie věd ČR uděleno zvláštní ocenění za nejlepší publikace Právníka k uvedenému výročí. Jednalo se o stati Mezinárodní smlouva jako možný perspektivní nástroj další evropské integrace $\mathrm{V}$. Týče a D. Sehnálka a Nahrazování směrnic nařízeními (dưvody, skutečnost, možnosti) F. Křepelky.

Kromě uvedeného se jednotliví členové katedry věnovali následujícím oblastem:

- V. Týč se v oblasti práva EU soustředil především na stupeň evropské integrace vhodnost či nevhodnost rozšiřování metody nadstátnosti. Taktéž publikoval rozsáhlou studii všestranně analyzující tzv. fiskální kompakt pod názvem Smlouva o stabilitě, koordinaci a správě v hospodářské a měnové unii z hlediska jejího dopadu na právní rád $\check{C} \boldsymbol{R}$. Dále se zabývá daňovou harmonizací v EU.

- F. Křepelka se autorsky zúčastnil na dvou dalších knižních publikacích: Sociální právo EU (2017) a Kompendium evropského ústavního práva (2017). Další výstupy F. Křepelky se ponejvíce týkaly zdravotnického práva a právní úpravy léčiv, včetně volného pohybu pacientů a zdravotnických služeb v EU. Dalšími tématy, o nichž pojednalo množství jeho výstupů, byla nap̌r. konzulární ochrana v EU, migrace, mnohojazyčnost EU, státní podpory, právo EU ve federacích, dluhová krize, volný pohyb služeb obecně a také např. problematika tzv. česko-slovenských důchodů. Zabývá se rovněž problematikou akademické samosprávy.

- D. Sehnálek po roce 2010 publikoval následující monografie: Vnější činnost Evropské unie perspektivou práva unijního a mezinárodního práva (2016), dále se spoluautorkou D. Ondrejovou: Vliv práva Evropské unie na českou regulaci nekalé soutěže a nekalých obchodních praktik (2016) a Nekalosoutěžní reklama a nekalé obchodní praktiky v české i evropské právní úpravě a judikatuře (2018). S V. Týčem redigoval konferenční sborník Soudní dvior EU a výklad práva Evropské unie (2016). Jeho další početné publikační výstupy se týkaly obecné části unijního práva (nap̌r. zásady effet utile, incidenčního účinku směrnice), nadstátní metody integrace, interpretace, unijního občanství, unijního dozoru nad dodržováním zásad právního státu aj.

- Publikační činnost J. Malenovského jakožto externího člena katedry zde kromě jeho učebnice nespecifikujeme, avšak nelze neuvést, že od jeho odchodu z fakulty v roce 1992 je neobyčejně bohatá, z větší části je zahraniční a týká se nejrůznějších témat jak mezinárodního, tak evropského práva.

- R. Charvát se věnuje oblasti duševního vlastnictví v mezinárodním a evropském právu. Je spoluautorem dvou velkých komentárư: Zákon o ochranných známkách (2017) a Zákon o ochraně průmyslových vzorů (2015). V roce 2016 vydal s V. Týčem obsáhlou publikaci Zeměpisná označení v mezinárodních smlouvách a v právu Evropské unie. Ve svých článcích a dalších výstupech řeší takové otázky jako vztah zeměpisných označení a konfliktních doménových jmen, vztah 
mezi ochrannými známkami a zeměpisnými označeními nebo dichotomii existence a výkonu práv k duševnímu vlastnictví, kterou zavedl Soudní dvůr EU. Také se zabývá unijní známkou a evropským patentem s jednotným účinkem.

\subsection{Pedagogická činnost - předměty a učebnice}

\subsubsection{Mezinárodni právo veřejné}

Povinný magisterský předmět Mezinárodní právo veřejné se nadále vyučuje jako dvousemestrální a je vybaven již uvedenou učebnicí J. Malenovského Mezinárodní právo veřejné: obecná část a poměr k jiným právním systémům (aktuálně 6. vyd. 2014), doplněnou pro zvláštní část rovněž již zmíněnou učebnicí autorů Potočný - Ondřej Mezinárodni právo verejné - zulástni cást.

$\mathrm{V}$ rámci MPV mají studenti možnost se přihlásit do semináře vedeného v anglickém jazyce. Ten představuje alternativu $\mathrm{k}$ seminářům základního předmětu. Je koncipován jako seminář pro studenty, kteří mají hlubší zájem o mezinárodní právo a o anglický jazyk. Vyučuje ho anglofonní irská lektorka Bríd Ní Ghráinne.

K doplnění základního kurzu MPV byly dlouhodobě vypsány dva povinně volitelné předměty. Je to Mezinárodní smlouva $\mathbf{v}$ mezinárodním, evropském a vnitrostátním právu V. Týče, pro který je učební pomůckou shora uvedená specializovaná publikace Mezinárodní, české a unijni právo mezinárodnich smluv (2013). Druhý předmět vytvořil P. Mrkývka z katedry finančního práva, který je honorárním konzulem Polské republiky v ČR. Nazývá se Konzulární praxe a obsahuje nejen konzulární, ale i diplomatické právo. Teoretickou část tohoto předmětu vyučuje V. Týč.

\subsubsection{Právo EU}

I zde pokračuje magisterský dvousemestrální povinný předmět Právo EU. V jeho rámci mají studenti možnost se přihlásit do výběrového dovednostního semináře. Ten představuje rozšíření a alternativu $\mathrm{k}$ seminářům základního předmětu. Je koncipován jako elitní semináŕ pro studenty, kteří mají hlubší zájem o právní aspekty evropské integrace. Probíhá pod vedením D. Sehnálka.

Kromě toho existují ve zkrácené verzi i dva předměty bakalářské (pro běžné bakalářské právnické studium a pro mezifakultní program Evropská studia). Používají se výše uvedená bakalářská skripta F. Křepelky a kol. Ve zkrácené anglické verzi se vyučuje také anglický předmět Law of the European Union, zejména pro zahraniční studenty.

Učebnice pro základní předmět jsou nyní dvě. Je to za prvé již 7. vyd. Základi̊ práva EU pro ekonomy V. Týče, a k tomu nová rozsáhlá kolektivní učebnice celostátního významu Právo Evropské unie za společné redakce M. Tomáška (Právnická fakulta UK v Praze) a V. Týče, která poprvé vyšla v roce 2013. Nyní je k dispozici její 
2. aktualizované vydání. Za katedru jsou členy autorského kolektivu rovněž J. Malenovský, F. Křepelka a D. Sehnálek. Pro seminární výuku D. Sehnálek připravil skripta Komentár̆ k vybrané judikatuře Soudního dvora EU(2013).

Pro magisterskou specializaci Veřejná správa je rovněž vyučován předmět Mezinárodní a evropské právo pro veřejnou správu.

Pokračuje nadále jednosemestrální předmět Úvod do mezinárodního a evropského práva vyučovaný povinně v prvním ročníku magisterského studia. Stejnojmenná skripta jsou k dispozici již ve 3. vydání.

Další povinně volitelné předměty $\mathrm{v}$ rozsahu jednoho semestru zahrnují mezinárodní a zejména evropské právo duševního vlastnictví. Bakalářský předmět se nazývá Mezinárodní ochrana práv duševního vlastnictví, magisterský Ochrana duševního vlastnictví v mezinárodním a evropském měřítku. Anglická verze pod názvem International and European Intellectual Property Law je určena jak pro české, tak zahraniční studenty. Všechny tyto předměty vyučuje R. Charvát, který také připravuje s V. Týčem pro tuto problematiku novou rozsáhlou odbornou publikaci. Zatím mají studenti k dispozici v elektronické formě již zpracované části této budoucí publikace.

Ve všech oblastech rovněž nadále probíhá výuka v doktorském studijním programu.

\subsubsection{Dalši souvisejicí činnosti}

S výukou úzce souvisejí zvláštní formy různých kurzů pro jiné než vlastní studenty. Jsou to např. letní školy. Ty jsou organizovány v oboru mezinárodního práva v rámci Academic Committee of Utrecht Network. Další takovou školou je PhD School on Antislavery and Trafficking, organizovaná ve spolupráci s britskými univerzitami. Každoroční zimní škola International Law and Human Rights pořádaná MU ve spolupráci s australskou stranou je určená především australským studentům (za katedru všechny organizuje K. Uhlírová).

D. Sehnálek naproti tomu organizuje Autumn School of Legal Writing and Related Global Legal Skills, což je specializovaný kurz zaměřený na výuku právních dovedností vyučovaný odborníky z USA, Rakouska, Švédska a Slovinska, organizovaný je společně s Rechtswissenschaftliche Fakultät, Universität Wien a s European Academy of Legal Theory.

Katedra také významně prrispěla k reprezentaci fakulty v zahraničí v rámci moot courtů, a to po mnoho let. K. Uhlírová působila již od roku 2010 jako vedoucí týmů v rámci studentských soutěží typu moot court v mezinárodním právu veřejném (Jessup Moot Court, ICRC Regional Moot Court, Jean-Pictet Moot Court a Telders International Law Moot Court Competition). Týmy dosahovaly opakovaně vítězná umístění ve vnitrostátních (českých) kolech (Best Memorial, Best Oralist and National Champion) a následně i v celosvětových či celoevropských soutěžích. 
D. Sehnálek vede od roku 2012 studentské týmy na soutěži Central and East European Moot Court pořádané British Law Centre, a to s velmi úspěšným umístěním.

D. Sehnálek a Z. Nový rovněž působili v soutěžích moot court jako rozhodci.

Pro oblast právo EU je také třeba zmínit pořádaní D. Sehnálkem každoročních společných studentských výjezdních seminářů s katedrou evropského práva PrF Univerzity Karlovy určených pro motivované a talentované studenty. Bohužel zájem studentů o tyto zajímavé akce stále klesá.

\section{Shrnutí}

Jak bylo výše popsáno, v období do roku 1990 bylo vše nesrovnatelně obtížnější než dnes. Proto také všechny zahraniční publikace, které se na katedru dostaly, byly velmi pečlivě prostudovány. Všechny zahraniční cesty, velmi vzácné, byly využity tak, aby ani minuta neprrišla nazmar. Jednodenní cesta do Vídně byla v té době téměř z říše snů. Snad jen v Haagu na letním kurzu Akademie mezinárodního práva se postupně vystř́idala celá katedra díky stipendiu nizozemské vlády, které nám zprostředkovalo naše ministerstvo školství. Publikačních výstupů bylo také nepoměrně méně než nyní, a proto je o nich pojednáno podrobněji.

$\mathrm{Na}$ rozdíl od tohoto období lze nyní cestovat do zahraničí bez omezení, přičemž tyto cesty jsou zpravidla díky grantovým nebo jiným prostředkům většinou finančně dostupné. Pokud jde o publikační činnost, nyní je možné volně publikovat cokoli, kdekoli, nikdo nic nekontroluje. Proto je také publikačních výstupů nepoměrně více, takže nebylo možné o všech podrobně referovat. Tento přehled tak v částech o vědecké a publikační činnosti uvádí u všech členů katedry jmenovitě zpravidla jen významné knižní publikace, zatímco u kratších výstupů (odborné články, prríspěvky ve sbornících) je uvedena jen tematická orientace autorů.

U pedagogické činnosti také nastaly velké změny. Starý rigidní systém omezený na povinné předměty byl nahrazen systémem flexibilnějším, kdy si studenti mohou vybírat povinně volitelné předměty podle svého zájmu. Zejména po roce 2004 mohou navíc absolvovat některé předměty na zahraničních univerzitách.

Změny ale nejsou jen pozitivní. V minulosti měli studenti větší motivaci studovat a větší zájem o zvolený obor. O tom svědčila pravidelná vysoká účast na nepovinných přednáškách. Na katedře nikdy nedocházelo k tomu, že by přednášející předčítal učebnici, což by byl důvod k neúčasti. Pravdou ovšem je, že na seminářích byla aktivita stejně mizerná, jako je tomu dnes.

V současné době jsme svědky prudkého poklesu zájmu studentů o jakékoli přednášky, a to i sebekvalitnější. Vypadá to, jakoby velká většina studentů o právo ztratila zájem a jakoukoli motivaci. Pro dnešní přednášející se stává výuka černou můrou. Účast na přednáškách je tak nízká (kolem 5 \%), že je otázkou, zda mají ještě vůbec smysl. 
Jsou-li přednášky nepovinné, znamená to pro většinu studentů automaticky, že je vůbec neberou v úvahu, a nezajímají se ani o jejich obsah. Kromě toho studenti většinou ani k př́pravě na zkoušku nepoužívají učebnic pro ně pracně napsaných a čtou si pochybné materiály stažené z internetu. Kromě nevelké skupiny studentů motivovaných - výborných a velmi dobrých - je úroveň velmi špatná, což je vidět i na stále se zhoršujících studijních výsledcích.

Závěrem k rozvoji oborů mezinárodní právo veřejné a právo EU. Z uvedeného přehledu výstupů je patrné, že katedra velmi výrazně přispěla k rozvoji obou oborů nejen na poli vědeckém, ale i pedagogickém. Její profesoři a docenti jsou významnými osobnostmi ve svých oborech, známými i v zahraničí. Je dobrý předpoklad k tomu, aby se i mladší členové katedry stali v blízké nebo nepř́liš vzdálené době takovými osobnostmi ve svých oborech. Naše brněnská katedra z tohoto hlediska nepochybně patří v národním i bývalém federálním kontextu k nejvýznamnějším a nejdynamičtějším pracovištím. 